\title{
Iranian EFL Learners' Social Intelligence (SI) and Willingness to Communicate (WTC): The Relationship and Difference across Gender
}

\section{Leila Ghalani ${ }^{1}$ \& Pantea Pahlavani ${ }^{* 2}$}

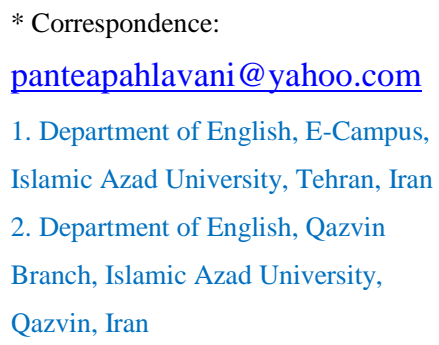

Received: 15 May 2019

Revision: 17 July 2019

Accepted: 19 August 2019

Published online: 20 September 2019

\begin{abstract}
Nowadays, English has become an international language and is used for communication and interaction among different countries and cultures across the world. So, the ability to communicate in a comprehensive way is one of the major goals of any second language educational setting. The aims of the present research were to investigate the relationship between Iranian EFL learners' social intelligence (SI) and their willingness to communicate (WTC) across gender, as well as to find out any possible difference between male and female learners in SI and their WTC relationship. To this end, 240 male and female EFL learners from different institutions were selected as the participants of the study with different age ranges based on convenient sampling. Then two standardized questionnaires, i.e., SI and WTC, were administered for all participants to answer. After collecting the required data and its analysis, the findings revealed a positive and significant correlation between male and female SI and their WTC. In addition, further statistical analysis using $Z_{o b c}$ formula showed no difference between learners' SI and WTC relationship across gender. The findings of the present research could be applicable for EFL learners, teachers, and material developers.
\end{abstract}

Keywords: EFL learners, gender, social intelligence, willingness to communicate 


\section{Introduction}

Nowadays, more than one billion native and non-native speakers apply English language all over the world as their first or second language and from this population, only one fourth are native speakers, whereas the rest use English as a second or foreign language in order to communicate with both native and non-native speakers of English (Strevens,1992). In this regard, scholars have claimed that the number of people who use English language continues to improve and this language is used in various areas including international trade, tourism, diplomacy, international media, air-traffic control, and technology (Ketabdar, Yazdani, \& Yarahmadi, 2014).

In this regard, second language (L2) pedagogy has attached great importance to communicative interaction in class with a view to developing learners' communicative competence. Individual learners; however, are not always willing to attempt L2communication. Therefore, many studies have been conducted to find out possible features promoting L2 communication. Willingness to Communicate (WTC) refers to the idea that language learners who are willing to communicate in L2 essentially try to find opportunities to communicate and at last they will really do communicate in the L2 (McCroskey \& Richmond, 1990). Given the personality trait of WTC, McCroskey and his associates proposed that WTC revealed a constant predisposition to talk, which was relatively consistent across various communication contexts and different types of receivers.

\subsection{Statement of the Problem}

Nowadays, modern language pedagogy holds a strong attention on authentic communication as a pivotal component of language learning. On the other hand, learners and any factor related to them could play a vital role in the success or failure of L2 learners' communication. So, it seems essential to consider individual differences as an important constraint which is affecting language learning outcomes (MacIntyre et al., 2001). In this regard, several individual difference (ID) factors perceived to facilitate L2 communication success, has been extensively studied in recent years (MacIntyre, 2007; MacIntyre, DÖrnyei, Clément, \& Noels, 1998; Yashima, 2002). Also, the issue of learners' gender on their possible success in L2 communication has been a controversial issue for doing different researches in the field of second language acquisition (Kocoglu, 1997; Machida, 2001; Rosenfeld \& Berko, 1990).

In recent years, although many studies have been carried out to explore L2 WTC in relation to comprehensible input (Kim, 2012 ), classroom size (Aubrey, 2010), and various ID variables such as personality, self-confidence, attitudes, motivation, and emotional intelligence (MacIntyre \& Charos, 1996; Yashima, 2002), it seems social intelligence (SI) i.e. a person's ability to accomplish relevant goals in particular social settings (Beheshtifar \& Roasaei, 2012) could be another essential concept of ID which can influence on second language learning success in general and L2 communication in specific.

In addition, a lot of researchers and scholars intend to achieve a deep view and opinion about the effective factors in maximal use of learners' abilities based on their cognitive dimension of performance and the effect of emotional aspects. For instance, several researches have been conducted on the relationship between social intelligence and academic achievements (Brown \& Anthony, 1990). Impact of some other variables on social intelligence has also been studied like creativity (Singh, 2007 as cited in Sexana \& Jain, 2009), gender and parents' occupation (Gnanadevan, 2007; Saxena \& Jain, 2009), interpersonal personality traits (Vyrost \& Kyselova, 2006), and age (Chesnokova, 2005). Despite the rich findings from previous researches, however, little effort has been devoted to studying L2 WTC in conjunction with social intelligence and this study had the propensity to fill the gap in literature. In fact, the aims of this study were to investigate the relationship between EFL learners' SI and their WTC in different genders and also to find out any possible difference in male and female EFL learners' SI and WTC relationships.

With respect to the review of literature, the researchers of the present study were convinced the relationship between L2 learners' WTC and their SI has not been explored yet; hence the present investigation was undertaken to initially explore the relationship between Iranian EFL learners' SI and their L2 WTC concerning two groups of female and male learners. Also, the researchers intended to investigate whether there is any difference between SI and WTC relationship across Iranian L2 learners' gender.

\subsection{Research Questions}

To examine the relationship between SI and WTC among Iranian female and male learners, as well as to investigate the difference between WTC and SI relationship across gender, the following research questions were taken into consideration: 
RQ1: Is there any statistically significant relationship between male and female Iranian EFL learners' SI and their WTC?

RQ2: Is there any difference in the relationship between Iranian EFL learners SI and their WTC across gender?

\subsection{Research Hypotheses}

Accordingly, the following research hypotheses were proposed.

H01: There is not any statistically significant relationship between male and female Iranian EFL learners' SI and their WTC.

H02: There is not any difference in the relationship between Iranian EFL learners SI and their WTC across gender.

\section{Review of the Related Literature}

\subsection{Willingness to Communicate}

Many scholars and researchers have made an attempt to define the term of Willingness to Communicate (WTC) from different perspectives. According to Richards and Schmidt (2002), WTC is the principle which learners should interact with specific goals via competencies. Barjasteh, Vaseghi, and Neissi (2011) also consider WTC as the extent to which learners are ready to start communication when they have a wide of choice. They also believe that WTC forms a factor believed to lead to individual differences in language learning.

According to Barjasteh et al. (2011), WTC is "the most basic orientation toward communication" (p.47). WTC is considered as a learner's "readiness to enter into discourse at a particular time with a specific person or persons, using a L2" (MacIntyre et al., 1998, p.547). McCroskey and Richmond (1987) also propose the concept of willingness to communicate via the term shyness, which refers to an individual's general personality orientation towards talking (as cited in MacIntyre \& Baker, 2001). Furthermore, it is clear that speaking is a focal point in interpersonal communication; however, different individuals tend to behave differently when they have the opportunity to strike up a conversation. According to MacIntyre and Baker (2001), WTC has been defined as the intention to initiate communication, when one has a choice.

WTC can be viewed as a personality trait and situational construct. As a personality trait, the conceptualization of WTC as a personality trait that is relatively in agreement across different communication contexts like public speaking and meeting as well as relatively stable with various receivers such as friends was nicely seized by researchers to absolve individual differences in L1 communication (McCroskey \& Baer, 1985; McCroskey \& Richmond, 1990). Dörnyei (2005) believes WTC in one's L1 is considered as a trait-like viewpoint which is developed over years and it should be interpreted as relatively stable. In other words, when a person communicates with his acquaintances a lot would also "be expected to be among those most willing to speak to strangers even if his/her WTC declines noticeably from acquaintances to stranger, and is the relative position in the distribution that is stable and not the absolute score for communicating in each context" (Zarrinabadi \& Tanbakoeii, 2016, p.31). This view of L1 WTC as a relatively stable over the time and across situations trait led second language researchers to examine the tendency of L2 speaking as a trait-like. MacIntyre and Charos (1996) introduced the notion of WTC to language learning and teaching literature and examined individuals' tendency to talk in an L2 (Zarrinabadi \& Tanbakooei, 2016).

As a situational construct, MacIntyre et al. (1998) developed a heuristic model that explained situational and enduring variables such as interpersonal motivation, intergroup motivation, self-confidence, intergroup attitudes, communicative competence, and personality, which influenced a person's level of L2 WTC resourcefully, contingently, and contextually. This multi-layered model was one of the most comprehensive and widely used theoretical frameworks of variables affecting WTC. The heuristic model considered the interrelations among the wide range of psychological, linguistic, and communicative variables influence WTC. In addition, MacIntyre (1994) developed a path model that illustrates WTC as a combination of higher communicative competence perceived by the learner and his lower level of communication anxiety. Afterwards, this model was implemented into L2 communication to postulate anxiety about L2 communication and perceived L2 communicative competence can consistently predict L2.

More recent studies have attempted to address the gap in research on WTC by collecting data from a range of sources and over a period of time. For example, Alemi, Daftarifard, and Pashmfroosh (2011) did a study to find out whether WTC model could explain the relationships between psychological and linguistic variables in Iranian context to predict 
students' WTC and they concluded that Iranian university students' WTC is directly related to their language proficiency but not language anxiety. Therefore, linguistic variables appear to be more predictive of WTC for Iranians, and language instructors should work on their students' English proficiency. In addition, Oz, Demirezon, and Pourfeiz (2015) investigated the EFL learners' perception on WTC and concluded communication competence and communication apprehension were the strong predictors of WTC while motivational factors indirectly influenced WTC. Furthermore, Al Murtadha (2018) did a study to find out possible factors which could influence on WTC. He found different teaching techniques like visualization lesson enhanced EFL learners' WTC. In the same vein, Lee (2019) concluded the extramural digital context would have a positive impact on learners' WTC.

\subsection{Social Intelligence}

Social intelligence (SI) as one of the new areas in the scope of psychology, in the recent decades, owing to its appealing and widespread dimensions has attracted the attention of psychologists, psychiatrists, and other experts in different scopes such as organization and management. This term was introduced by psychologist Edward Thorndike who improved the original conceptualization of social intelligence in 1920 as a mental ability distinct from abstract and mechanical intelligence. He defines social intelligence as "the ability to act wisely in human relations" (p.228). SI is considered as a keen awareness of the value of social connections, the ability to take another's perspective, and the capacity to engage in satisfying relationships (Goleman, 2006). Also, SI can be considered as "an inclusive term that embraces a wide range of skills and personal characteristics and usually refers to those interpersonal and intrapersonal skills that transcend specific areas of the previous knowledge such as intelligence and technical or professional skills" (Rezayee \& Khalilzadeh, 2009, as cited in Ebrahimpour, Zahed, \& Elyasi, 2013, p.5). Moreover, Ford and Tisak (1983) look at social intelligence as behavioral outcomes. They define social intelligence as "one's ability to accomplish relevant objectives in specific social settings" (p.197). In the same vein, SI can be defined as "the ability to control emotions and feelings; therefore it can help mental activities, decision making, and communication." Accordingly, those with "high social intelligence, know how to monitor and channel their own and others' emotions and feelings" (Goalman, 1998, p. 94).

For some scholars like Marlowe (1986), SI is equated with social competence and it refers to "the ability to understand the feelings, thoughts, and behaviors of persons, including oneself, in interpersonal situations and to act appropriately upon that understanding" (p.52). More recently, Goleman's (2006) definition of SI considers it as two broad categories, i.e. social awareness and social facility. Social awareness refers to "what we sense about others" and social facility refers to "what we then do with that awareness" (p.84). SI involves four components including social skills, social information processing, social awareness, and social desirability. Social skills are important factors in "understanding and receiving comments on one's performance and learn from failure" (Ebrahimpoor et al., 2013, p.6). Next, social information illustrates one's "capability to regulate distressing emotions like anxiety or nervousness and managing such situations" (Ebrahimpoor et al., 2013, p.6). Social awareness happens when an "individual identifies the paradoxical situations via becoming aware of others' feelings, tastes, and needs" (Aristu, Tello, Orttiz, \& Gardarn, 2008, p.25). Finally, social desirability denotes "how to communicate and interact with learners in the emotional situations which is also referred as social skill" (Nwkah \& Ahizu, 2009, p.867). According to Goleman (2006), those who intend to make relationships with others effectively require to have the capability of determining, separating, and controlling their feelings.

More recent studies have attempted to address the gap in research on SI. For instance, Praditsang, Hanafi, and Walters (2015) investigated the relationship among emotional intelligence, social intelligence, and learning behavior among first-year students at a university in southern Thailand. The findings revealed that father's education was negatively significant with learning behavior. Emotional intelligence was not significantly related with learning behavior. However, social intelligence was significantly related with learning behaviour, except for social cognition, selfpresentation, influence, and concern. Zarafshan and Ardeshiri (2012) investigated the relationship between emotional intelligence, language learning strategies, and English proficiency among Iranian EFL university students. The results revealed that there was a negative relationship between emotional intelligence and English proficiency but a positive relationship was found between English proficiency and use of language learning strategies. Metacognitive and affective strategies tended to affect English proficiency more. Social strategies were the least effective. Moreover, Bennett (2015) compared the social intelligence of distance undergraduates with the social intelligence of traditional undergraduates at different class ranks. The results showed no statistically significant difference in the level of social intelligence between distance and traditional undergraduates. There was a statistically significant difference in the 
level of social intelligence among undergraduate class ranks, and there was no significant difference between learning environments in social intelligence across levels of class rank.

\section{Methodology}

\subsection{Design of the Study}

As the nature of the current research was to seek the relationship between male and female learners' SI and WTC, the present study enjoyed a correlational design and the participants were selected based on non-random and convenient sampling, i.e., a sample of non-probability sampling where the participants are chosen based on their accessibility, availability, and proximity to the researcher (Goddard \& Melville, 2004).

\subsection{Participants}

The participants of this study were 240 language learners, both female and male ones in equal number. They were selected from different language institutes in Tehran, with age ranges of 19 to 25 . All participants were chosen based on convenient sampling and their willingness to participate in the current study. All selected participants were studying English at intermediate level of language proficiency and as the foreign language. Table 1 summarizes the demographic information about the participants.

Table1. Participants of the study

\begin{tabular}{llll}
\hline Participants & $\mathrm{N}$ & Level & Age range \\
\hline Female & 120 & intermediate & $19-25$ \\
Male & 120 & intermediate & $19-25$
\end{tabular}

\subsection{Instruments}

In order to accomplish the purposes of this study, two standardized questionnaires were utilized by the researchers.

\subsubsection{Social Intelligence Questionnaire}

The first utilized questionnaire in the present study was the social intelligence questionnaire developed by Silvera, Martinussen, and Dahl (2001). This questionnaire consists of 21 items in a five-point Likert scale to measure different behaviors, thought processes, and mental characteristics. The participants were asked to respond all items honestly. The provided answers are in a range of 1 to 5 as $1=$ Almost never, $2=$ Sometimes, $3=$ Half of the time, $4=$ Usually, and $5=$ Almost always. Also, the reported reliability of this questionnaire was .79 (See Appendix A). In addition, the researchers of the present study piloted this questionnaire to $60 \mathrm{EFL}$ learners with the similar characteristics of the representative sample, and the reliability was reported as $\mathrm{r}=.75$.

\subsubsection{Willingness to Communicate (WTC) Questionnaire}

This scale was first designed by MacIntyre, Baker, Clément, and Conrod (2001), and it operationalizes L2 WTC in four basic skill areas such as listening, speaking, reading, and writing, measuring students' willingness to engage in second language communication inside or outside the classroom. WTC questionnaire comprises of 27 items which range from 1 to 5 or a five-point Likert scale as $1=$ almost never willing, $2=$ sometimes willing, $3=$ willing half of the time, $4=$ usually willing, and $5=$ almost always willing. The participants were asked to read all questions and reply them based on their degree of willingness (See Appendix B).

MacIntyre et al. (2001) report this scale to be a valid and reliable one (alpha levels indicate reliability estimates): speaking ( 8 items, $\alpha=.81$ ), comprehension ( 5 items, $\alpha=.83$ ), reading (6 items, $\alpha=.83$ ), and writing ( 8 items, $\alpha=.88$ ), this scale includes both productive (speaking $\&$ writing) and receptive skills (reading $\&$ comprehension) whereas receptive skills may foster the learners WTC in other areas of language use, if given the opportunity (Ahmadi et al., 2015). Also, the researchers of the present study piloted this questionnaire to 60 EFL learners with the similar characteristics of the representative sample, and the reliability was reported as $\mathrm{r}=.82$. 


\subsection{Data Collection}

As the main objectives of the present study were to investigate the relationship between Iranian male and female EFL learners' WTC and their social intelligence and the possible difference between WTC and social intelligence relationship across learners' gender, the researchers followed some steps to this end. First of all, they got the permission of different institutions to have access to their classrooms, as well as students. Next, to ensure the reliability of the utilized instruments, they were administered for 60 L2 learners with the same characteristics of the target population in the study. The reported reliability was 0.78 which was an accepted index. Also, the content validity of the questionnaires was checked by two university professors in TEFL to ensure the questionnaires were suitable for measuring the learners' WTC and SI. Then, the participants of the study were selected based on availability for the researchers, as well as their willingness to attend in the present research. In other words, participation in this research was voluntary. Also, the researchers presented the consent form, which included detailed information about the research and assures confidentiality. While the participants were answering the questionnaire, the researchers were present in the classrooms to explain or clarify the items which were ambiguous or intangible for the respondents. The process of data collection took almost two months and all questionnaires were gathered in pan and paper forms.

\subsection{Data Analysis}

The completed questionnaires were collected, scored, and analyzed by the researchers and those questionnaires which were not answered completely or inappropriately were discarded. Accordingly, the raw data collected from 240 questionnaires were analyzed by the researchers utilizing SPSS software to answer the research questions. In order to answer the research questions, the researchers utilized descriptive statistics like mean, standard deviation, Kurtosis, and skeweness ratio. Also, inferential statistics, i.e., coefficient correlation and $Z_{o b c}$ formula were utilized to answer the two research questions.

\section{Results}

Before answering the research questions of this study, it was needed to check a number of assumptions and perform some preliminary analyses. These analyses would determine the legitimacy of running the analyses along with the type of statistical techniques, i.e. parametric or non-parametric. To begin with, the assumptions of interval data and independence of participants were already met as the present data were measured on an interval scale and the participants were independent of one another. In addition, it was needed to check the normality assumptions of the distribution of variables including, linear relation between each pair of variables, homoscedasticity, and normality of the distribution of variables (Tabachnick \& Fidell, 2007). To check the linearity of relations, the researchers needed to visually inspect the data through creating scatterplots. Since there were several variables in the study, and based on the focus of the three research questions, the researchers created a multiple scatterplot which is presented Figure 1.
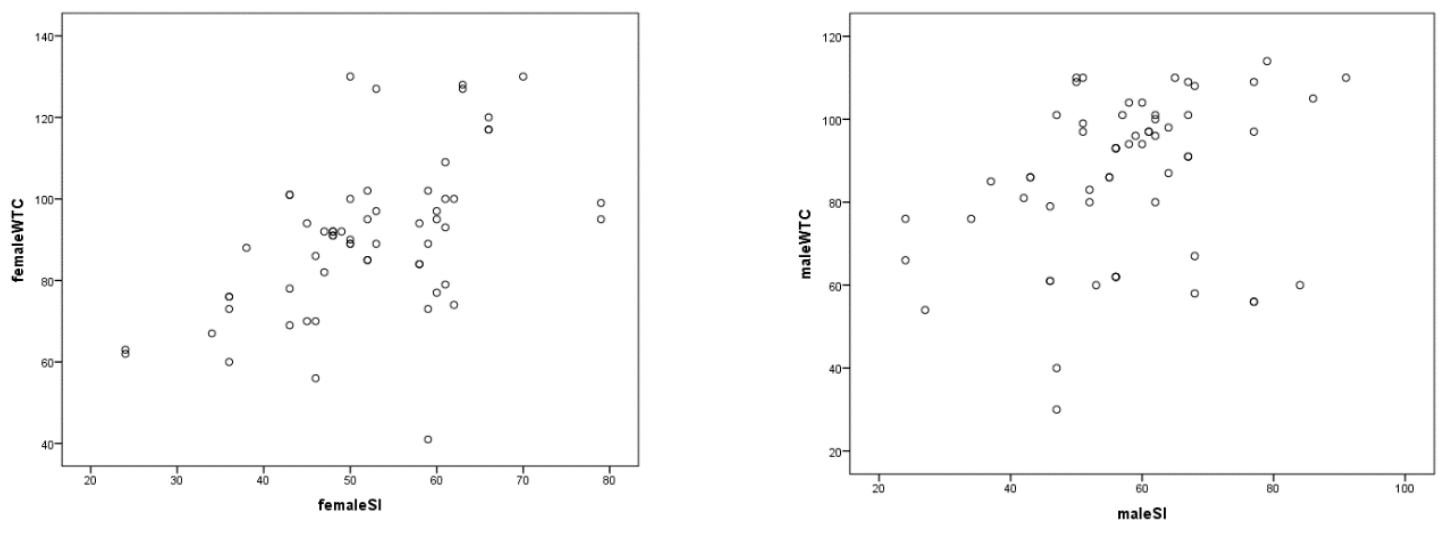

Figure1. The scatter plots of learners' WTC and SI across gender 
Through inspecting scatterplot of learners' WTC and SI across gender, it can be inferred that the relationships among these variables are almost linear. As it can be observed, there is not a U-shaped or curvilinear pattern of distribution. Consequently, the linearity of relations can be confirmed. In addition, the distribution of scores was not a funnel shape, i.e., wide at one end and narrow at the other; therefore, the assumption of homoscedasticity was met for these variables. In order to check the normality of the distributions, two procedures were followed. First, Table 2 shows the Kolmogorov-Smirnov test was run as a further attempt to inspect the normality of the distributions. Second, the descriptive statistics of the data were obtained and kurtosis and skewness ratios were calculated.

Table 2. Tests of normality

\begin{tabular}{llll}
\hline & \multicolumn{3}{l}{ Kolmogorov-Smirnova } \\
\cline { 2 - 4 } & Statistic & df & Sig. \\
\hline Female WTC & .119 & 120 & .035 \\
Female SI & .101 & 120 & $.200^{*}$ \\
Male WTC & .139 & 120 & .005 \\
Male SI & .090 & 120 & $.200^{*}$ \\
\hline
\end{tabular}

*. This is a lower bound of the true significance.

a. Lilliefors Significance Correction

As the $p$ value for male and female participants' SI is more than .05 , and the normality of distribution for these scores is supported, but for female and male WTC the Sig. value is less than .05. This point suggests that the assumption of normality is violated for female and male learners' WTC variable. Also, the descriptive statistics related to the obtained scores on the instruments, including the calculated values of skewness ratio and kurtosis ratio, appear below in Table3.

Table 3. Descriptive statistics of scores obtained from WTC and SI across gender

\begin{tabular}{lllll}
\hline & & Statistic & Std. Error Ratio \\
\hline Female WTC & Mean & 90.40 & 2.427 & \\
& Std. Deviation & 18.796 & & \\
& Minimum & 41 & & \\
& Maximum & 130 & & \\
& Range & 89 & & \\
& Interquartile Range & 23 & & \\
& Skewness & .144 & .309 & .46 \\
& Kurtosis & .328 & .608 & .53 \\
\hline Female SI & Mean & 52.10 & 1.448 & \\
& Variance & 125.753 & & \\
& Std. Deviation & 11.214 & & \\
& Minimum & 24 & & \\
& Maximum & 79 &
\end{tabular}




\begin{tabular}{lllll}
\hline & Skewness & -.141 & .309 & -.45 \\
& Kurtosis & .473 & .608 & .77 \\
\hline Male WTC & Mean & 85.97 & 2.543 & \\
& Std. Deviation & 19.699 & & \\
& Minimum & 30 & & \\
& Maximum & 114 & & \\
& Skewness & -.762 & .309 & -2.46 \\
& Kurtosis & -.131 & .608 & -.21 \\
\hline Male SI & Mean & 57.40 & 1.799 & \\
& Std. Deviation & 13.933 & & \\
& Minimum & 24 & & \\
& Maximum & 91 & & \\
& Skewness & -.093 & .309 & 0.30 \\
& Kurtosis & .521 & .608 & 0.85 \\
\hline
\end{tabular}

As demonstrated in Table 3, if both skewness ratio and kurtosis ratio values fall within the range of -1.96 and +1.96 , this point can support the normality of distribution for the scores (Tabachnick \& Fidell, 2007). Accordingly, male and female learners' SI and WTC were considered normal, whereas male learners' WTC was not considered normal. In this regard, the researchers concluded that the data did not meet the assumptions of parametric statistical techniques, so the first research question was answered through employing non-parametric test. As stated earlier, the first driving force behind conducting this study was to systematically investigate the relationship between Iranian male and female learners' WTC with their SI. In order to answer this question, the data were analyzed using the Spearman coefficient of correlation. Table 4 shows the result of this analysis.

Table 4. Correlations between SI and WTC

\begin{tabular}{lllll}
\hline & & Male WTC & Female WTC \\
\hline Spearman's rho & Male SI & Correlation Coefficient & $.343^{* *}$ & \\
& & Sig. (2-tailed) & .007 & \\
& $\mathrm{~N}$ & 120 & \\
\cline { 3 - 4 } & & & $.520^{* *}$ \\
& Female SI & Correlation Coefficient & .000 \\
& Sig. (2-tailed) & 120 \\
& $\mathrm{~N}$ & & 120 \\
\hline
\end{tabular}

**. Correlation is significant at the 0.01 level (2-tailed).

According to the results of the analysis reported in Table 4, it was concluded that there was a significant and positive correlation between Iranian male learners' SI and WTC as $r=0.343, n=120, p<.05$. Also, it was found a significant and positive correlation between Iranian female learners' SI and WTC as $\mathrm{r}=0.520, n=120, p<.05$.

The second research question of this study sought to find the difference in the relationship between Iranian EFL female and male learners' WTC and SI. In order to answer this question, the researchers utilized the $Z_{o b c}$ equation to calculate 
the significant difference between two groups (Pallant, 2007). In order to calculate this difference, at first, it was measured the $\mathrm{r}$ value obtained from two groups was converted into a standard score form known as $\mathrm{Z}$ score. Accordingly the standard score for female and male learners' were $\mathrm{z} 1=0.576$, and $\mathrm{z} 2=0.360$, respectively. Based on the $Z_{o b c}$ formula, If the $Z_{o b c}$ value is between -1.96 and +1.96 , there is not a significant difference between the two correlation coefficient.

$$
Z_{o b c}=\frac{\mathrm{z} 1-\mathrm{z} 2}{\sqrt{\frac{1}{\mathrm{n} 1-3}+\frac{1}{\mathrm{n} 2-3}}}
$$

Based on the above equation and numerical statistics, $Z_{o b c}$ was calculated as 1.66 . Accordingly, there was not a statistically significant difference between Iranian EFL learners' WTC and their SI relationship, across gender.

\section{Discussion}

The researchers in this study examined the relationship between Iranian EFL learners' WTC with their SI as well as to check the possible difference of this relationship across learners' gender. Although this study was conducted in one city and several language institutions with limited number of EFL learners as well as administrating two questionnaires for WTC and SI measurement, the relationship between WTC and SI was proved. Also, this relationship was not different among male and female learners. In this section, the results of the study are compared and contrasted in relation to the previous findings in order to test the research hypotheses of the study.

Gkonou and Mercer (2017, p.6) assert "SI centers on people's interpersonal awareness and social facility, their ability or skill to deal with social relationships effectively, co-operate and collaborate with others, and create and participate in healthy, positive and caring social interactions." Accordingly, it seems a learner with higher SI could have more motivation and interest to communicate with others and the findings of the present study verify this issue.

In addition, they believe SI and emotional intelligence (EI) are linked closely regardless of a distinguishable difference between them, i.e. focusing of EI on one-person psychology within an individual as opposed to the two-person psychology mirrored in SI and stemming from social interactions and interpersonal relationships (Goleman, 2006). In this regard, the findings of the previous studies which have shown a positive and significant correlation between WTC and EI (Ketabdar, Yazdani, \& Yarahmadi, 2014; Rahbar, Suzani, \& Sajadi, 2016; Tabatabei \& Jamshidifar, 2013), can assert on the possible relationship between WTC and learners' SI, as well.

Furthermore, according to Martin and Dawson (2009), SI is closely connected to "interpersonal energy" (p.330), which is mainly derived from participation in social interactions and groups. So, the more a person has higher SI, the more interpersonal energy s/he may have, and it can be assumed s/he has higher willingness to communicate.

The other finding of the present study showed the correlation between learners' WTC and their SI was higher among female learners. In the same vein, Meshkat and Nejati (2017) found no difference between male and female EFL learners' EQ but the genders did tend to differ in emotional self-awareness, interpersonal relationship, self-regard, and empathy with females scoring higher than males.

However, Gholami (2015) concluded female EFL learners were as the outperforming group both in terms of emotional intelligence and willingness to communicate. Also, Naghavi and Redzuan (2011) found the difference between females and males in their EQ. Finally, Wright (1999) reports some researches that demonstrate more positive attitudes toward language learning among females compared to males. Also, he believes as females reach the maturity earlier than males, this may help them become dedicated in learning tasks.

Finally, there was no significant difference between male and female learners regarding to their WTC and SI relationship. In other words, gender did not play a significant role in the correlation between WTC and SI. The researchers assume it may be due to the similar learning contexts, learning background, and demographic characteristics which all learners shared with each other.

\section{Implications}

As WTC seems one of the factors influencing language learners' propensity to communicate in an ESL/EFL contexts, and several factors within or surrounding learners, such as their SI, might affect their decisions to communicate their meanings through L2 language they are learning, the importance of the findings in the present study lies not only in their contribution to the literature but also in their prominent educational importance for teachers, learners, and 
material developers. Teachers can gent benefit from the findings of the present research to identify their learners' SI and WTC in order to provide methodological and teaching strategies to enhance their learners' practice in authentic communication. Moreover, the findings of the present study would be applicable for learners. The awareness of their SI and its relationship with WTC could encourage them to enhance their SI in order to have higher WTC which leads to more successful communication which is the ultimate goal of each L2 learner. Finally, the results can help both practitioners and material developers to highlight the importance of learners' WTC and SI to design tasks and materials which would be more student-centered rather than teacher-centered and to promote learners' WTC and SI in L2 communication.

\section{Conclusion}

Despite the emphasis on communication in modern language pedagogy and the well accepted view that learners require practice in speaking in order to learn, some language learners habitually choose to remain silent. The present study aimed at investigating the relationship between WTC and SI across gender. Also, the second driving force of the present research was to identify any possible difference in WTC and SI relationship across male and female learners. The results indicated both male and female learners' WTC had a significant relationship with their SIs. Furthermore, no significant difference was found between male and female learners regarding their WTC and SI relationship. This study contributes to better understanding of the relationship between L2 learners' WTC and SI in the process of second language learning in a way to help educators develop innovative teaching materials and upgrade the pedagogical practices, as well as empower learners to go through in a positive and lifelong learning experience. It is hoped that the experience shared in this study will inspire further research studies and lead to closer partnership between teachers and students so that students are given more choices to practice in the process of L2 learning.

\section{References}

Alemi, M., Daftarifard, P., \& Pashmforoosh, R. (2011). The Impact of language anxiety and language proficiency on WTC in EFL context. Cross-cultural Communication, 7(3), 150-166. doi: 10.3968/j.ccc.1923670020110703.152

Aristu, A. L., Tello, F. P. H., Orttiz, M. A., \& Gandarn, M. (2008). The structure of Bryant's empathy index for children: A croo-validation study. Journal of Psychology, 11(2), 670-677. https://doi.org/10.1017/S1138741600004674

Al Murtadha, M. (2018). Enhancing EFL learners' willingness to communicate with visualization and goal setting activities. TESOL Quarterly, 53(1), 133-158. https://doi.org/10.1002/tesq.474

Aubrey, S. C. (2010). Influences on Japanese students' willingness to communicate across three different sized EFL classes. Retrieved from https://www.asian-efl-journal.com/2239/thesis/influences-on-japanese-studentswillingness-to-communicate-across-three-different-sized-efl-classes/\#squelch-taas-tab-content-0-3

Barjastehe, H., \& Vaseghi, R., \& Naessi, S. (2011). Iranian EFL learners' willingness to communicate across different context- and receiver-types. International Journal of English Linguistics, 2(1), 47-54. doi: 10.5539/elt.v9n5p33

Beheshtifar, M., \& Roasaei, F. (2012). Role of social intelligence in organizational leadership, European Journal of Social Sciences, 28(2), 200-206. Available at http://flexmanager.ir/downloads/EJSS 28_2 03.pdf

Bennett, B. S. (2015). Social intelligence of undergraduates enrolled in traditional vs. distance higher education learning programs. Retrieved from https://pdfs.semanticscholar.org/f254/27ec37d73a182ec7bc874cd238ac5960ac9e.pdf

Brown, L. T., \& Anthony, R. G. (1990). Continuing the search for social intelligence. Personality and Individual Differences, 11(5), 463-470. http://dx.doi.org/10.1016/0191-8869(90)90059-Z

Chesnokova, O. (2005). Cunning and social intelligence in children. www.lancs.ac.uk

Dörnyei, Z. (2005). The psychology of the language learner: individual differences in language acquisition. Mahwah, N. J.: Lawrence Erlbaum. doi: 10.4324/9781410613349

Ebrahimpour, H., Zahed, A., \& Elyasi, A. (2013). The study of relationship between social intelligence and organizational performance. International Journal of Organizational Leadership, 2(1), 4-13. Available at https://pdfs.semanticscholar.org/9297/4df6ece65e34ad8c440eec4e9e0b1a892532.pdf 
Ford, M. E., \& Tisak, M. S. (1983). A further search for social intelligence. Journal of Educational Psychology, 75(2), 196-206. doi: http://dx.doi.org/10.1037/h0035988

Gnanadevan, R. (2007). Social intelligence of higher secondary students in relation to their socio-economic status. Journal of Community Guidance and Research, 24(3), 340-346. Available at http://www.mierjs.in/ojs/index.php/mjestp/article/viewFile/6/5

Gholami, L. (2015). Willingness to communicate and its relationship with emotional intelligence and gender differences. International Letters of Social and Humanistic Sciences Online, 52, 87-94. https://doi.org/10.18052/www.scipress.com/ILSHS.52.87

Gkonou, C., \& Mercer, S. (2017). Understanding emotional and social intelligence among English language teachers. Discussion Paper. British Council ELT Research Papers. Retrieved from https://englishagenda.britishcouncil.org/sites/default/files/attachments/g211_eltra_gkonou_and_mercer_paper final web.pdf

Goddard, W., \& Melville, S. (2004). Research methodology: An introduction (2nd edition). NY: Blackwell Publishing.

Goleman, D. (1998). What makes a leader? Harvard Business Review, 76(6), 93-102. Available at https://icenamor.github.io/files/What-makes-a-leader.pdf

Goleman, D. (2006). Social intelligence: The new science of human relationships. London: Arrow Books. Available at https://epdf.pub/social-intelligence-the-new-science-of-human-relationships.html

Ketabdar, Z., Yazdani, S., \& Yarahmadi, M. (2014). The relationship between emotional intelligence and willingness to communicate among Iranian EFL Learners. European Online Journal of Natural and Social Sciences, 3(3), 637-650. Available at http://european-science.com/eojnss/article/view/1327/pdf

Kim, K. (2012). L2 phone-based interaction (PBI) and development of communicative competence: A case study of an adult's English learning in EFL context. Asian EFL Journal, 14, 99-177. Available at https://www.asianefl-journal.com/main-journals/12-phone-based-interaction-pbi-and-development-of-communicativecompetence-a-case-study-of-an-adults-english-learning-in-efl-context/\#squelch-taas-tab-content-0-3

Kocoglu, Z. (1997). The role of gender on communication strategy use. Retrieved from https://files.eric.ed.gov/fulltext/ED409725.pdf

Lee, J. S. (2019). EFL students' views of willingness to communicate in the extramural digital context. Computer Assisted Language Learning, 1-21.doi: $\underline{10.1080 / 09588221.2018 .1535509}$

Machida, S. (2001). Anxiety in Japanese-language class oral examinations. Sekai no Nihongo Kyoiku, 11, 115-138.

MacIntyre, P. D. (1994). Variables underlying willingness to communicate: A causal analysis. Communication Research Reports, $11(2), 135-142$. https://doi.org/10.1080/08824099409359951

MacIntyre, P. D. (2007). Willingness to communicate in the second language: Understanding the decision to speak as a volitional process. The Modern Language Journal, 91(4), 564-576. https://doi: 10.1111/j.15404781.2007.00623.x https://www.jstor.org/stable/4626086

MacIntyre, P. D., Baker, S. C., Clement, R., \& Conrod, S. (2001). Willingness to communicate, social support,and language learning orientation of immersion students. SSLA, 23(3), 369-388. Available at http://citeseerx.ist.psu.edu/viewdoc/download?doi=10.1.1.542.9753\&rep=rep1\&type=pdf $\quad$ doi: $10.1017 / \mathrm{S} 0272263101003035$

MacIntyre, P. D., Baker, S. C., Clement, R., \& Donovan, L. A. (2003). Talking in order to learn: Willingness to communicate and intensive language programs. Canadian Modern Language Review, 59(4), 589-607. http://dx.doi.org/10.3138/cmlr.59.4.589

MacIntyre, P. D., \& Charos, C. (1996). Personality, attitudes, and affect as predictors of second language communication. Journal of Language and Social Psychology, 15(1), 3-26. http://dx.doi.org/10.1177/0261927X960151001 
MacIntyre, P. D., Dornyei, Z., Clement, R., \& Noels, K. A. (1998). Conceptualizing willingness to communicate in L2: A situational model of L2 confidence and affiliation. The Modern Language Journal, 82(24), 545562.http://dx.doi.org/10.1111/j.1540-4781.1998.tb05543.x

Marlowe, H. A. (1986). Social intelligence: Evidence for multi dimensionality and construct independence. Journal of Educational Psychology, 78(1), 52-58. http://dx.doi.org/10.1037/0022-0663.78.1.52

Martin, A. J., \& Dowson, M. (2009). Interpersonal relationships, motivation, engagement, and achievement: Yields for theory, current issues, and educational practice. Review of Educational Research, 79(1), 327-365. https://doi.org/10.3102/0034654308325583

McCroskey, J. C., \& Baer, J. E. (1985). Willingness to communicate: The construct and its measurement. Paper presented at the annual meeting of the Speech Communication Association (71st, Denver, CO, November 710, 1985).

McCroskey, J. C., \& Richmond, V. P. (1987). Willingness to communicate. In McCroskey JC, Daly JA (eds) Personality and interpersonal communication (pp.129-156). Newbury Park, CA: Sage Publications.

McCroskey, J. C., \& Richmond, V. P. (1990). Willingness to communicate differing cultural perspectives. The Southern Communication Journal, 56(1), 72-76. https://doi.org/10.1080/10417949009372817

Meshkat, M., \& Nejati, R. (2017). Does emotional intelligence depend on gender? A study on undergraduate English majors of three Iranian universities. Sage Open, 7(3). Retrieved from https://journals.sagepub.com/doi/pdf/10.1177/2158244017725796 https://doi.org/10.1177/2158244017725796

Naghavi, F., \& Redzuan, M. (2011). The relationship between gender and emotional intelligence. World Applied Sciences Journal 15(4), 555-561. https://pdfs.semanticscholar.org/63c3/184d107e804db1b7701a752f6f27d11b2c56.pdf

Nwkah, N. G., \& Ahiauzu, A. L. (2009). Emotional intelligence and marketing effectives. Marketing Intelligence \& Planning, 27(7), 867-881. doi: 10.1108/02634500911000199

Öz, H., Demirezen, M., \& Pourfeiz, J. (2015). Willingness to communicate of EFL learners in Turkish context. Learning and Individual Differences, 37, 269-275. https://doi.org/10.1016/j.lindif.2014.12.009

Pratisang, M., Hanafi, Z., \& Walter. T. (2015). The relationship among emotional intelligence, social intelligence and learning behavior. Asian Social Science, 11(13), 98-107. doi: 10.5539/ass.v11n13p98

Rahbar, B., Suzani, M., \& Sajadi, Z. (2016). The relationship between emotional intelligence and willingness to communicate among Iranian intermediate EFL learners. Journal of Language Teaching: Theory and Practice, 2(3), 10-17. Available at http://jlttp.ir/files/uploads/2016/10/2.2-Rahbar-et-al..pdf

Richards, J. C., \& Schmidt, R. (2010). Longman dictionary of language teaching and applied linguistics. London: Longman Pearson Education. https://doi.org/10.4324/9781315833835

Rosenfeld, L.W., \& Berko, R. M. (1990).Communicating with competency. NY: Foresman \& Company.

Saxena S., \& Jain, K. R. (2009). Social intelligence of undergraduate students in relation to their gender and subject stream. IOSR Journal of Research \& Method in Education, 1(1), 1-4. https://doi.org/10.9790/7388-0110104

Silvera, D. H., Martinussen, M., \& Dahl, T. I. (2001). The Tromso social intelligence scale, a self-report measure of social intelligence. Scandinavian Journal of Psychology, 42(4), 313-319. https://doi.org/10.1111/1467$\underline{9450.00242}$

Strevens, P. (1992). English as an international language. In B. B. Kachru (Eds.), The other tongue: English across cultures (pp. 27-47). Urbana: University of Illinois Press. doi: 10.2307/376966

Tabachnick, B. G., \& Fidell, L. S. (2007). Using multivariate statistics. Boston, MA: Pearson Education, Inc. https://doi.org/10.1007/978-3-642-04898-2_394 
Tabatabaei, O., \& Jamshidifar, M. (2013). The relationship between emotional intelligence and willingness to communicate among EFL learners. International Journal of English Language Education, 2(1), 90-99. https://doi.org/10.5296/ijele.v2i1.4650

Vyrost, J., \& Kyselova, M. (2006). Personality correlates of social intelligence. Studia Psychologica, 48(3), 207-212. Available at $\quad$ http://www.elis.sk/index.php?page=shop.product_details\&flypage=flypageask.tpl\&product $\mathrm{id}=1166 \&$ category $\mathrm{id}=39 \&$ option $=$ com virtuemart\&Itemid=1

Wright, M. (1999). Influences on learner attitudes towards foreign language and culture. Educational Research, 4l(2), 197-208. https://doi.org/10.1080/0013188990410207

Yashima, T. (2002). Willingness to communicate in a second language: The Japanese EFL context. The Modern Language Journal, 86(1), 54- 66. https://doi.org/10.1111/1540-4781.00136

Zarafshan, M., \& Ardeshiri, M. (2012). The relationship between emotional intelligence, language learning strategies and English proficiency among Iranian EFL university students. Journal of Educational and Instructional Studies in the World, 2(3), 105-114. Retrieved from https://pdfs.semanticscholar.org/a271/a136d491108e35a1e540b302d7b43e49bf3b.pdf

Zarrinabadi, N., \& Tanbakooei, N. (2016).Willingness to communicate: Rise, development, and some future direction. Language and Linguistics Compass, 10(1), 30-45. https://doi.org/10.1111/lnc3.12176 


\section{Appendices}

\section{Appendix A: Social Intelligence Self-report Inventory}

Directions: This questionnaire is composed of some statements concerning your social skills and intelligence. Please indicate what you think based on the following numbers (Developed by Silvera, Martinussen, \& Dahl, 2001)

$1=$ Almost never, $2=$ Sometimes, $3=$ Half of the time $4=$ usually, $5=$ Almost always

1. I can predict other peoples' behavior.

2. I often feel that it is difficult to understand others' choices.

3. I know how my actions will make others feel.

4. I often feel uncertain around new people who I don't know.

5. People often surprise me with the things they do.

6. I understand other peoples' feelings.

7. I fit in easily in social situations.

8. Other people become angry with me without me being able to explain why.

9. I understand others' wishes.

10. I am good at entering new situations and meeting people for the first time.

11. It seems as though people are often angry or irritated with me when I say what I think.

12. I have a hard time getting along with other people.

13. I find people unpredictable.

14. I can often understand what others are trying to accomplish without the need for them to say anything.

15. It takes a long time for me to get to know others well.

16. I have often hurt others without realizing it.

17. I can predict how others will react to my behavior.

18. I am good at getting on good terms with new people.

19. I can often understand what others really mean through their expression, body language, etc.

20. I frequently have problems finding good conversation topics.

21. I am often surprised by others' reactions to what I do. 


\section{Appendix B: WTC Questionnaire}

Directions: This questionnaire is composed of some statements concerning your feelings about communication with other people, in English. Please indicate the frequency of time you choose to speak in English in each classroom situation (adapted from MacIntyre, Baker, Clément, \& Conrod, 2001).

$1=$ Almost never willing, $2=$ Sometimes willing, $3=$ willing half of the time $4=$ usually willing, $5=$ Almost always willing

1. Speak in a group about your summer vacation

2. Speak to your teacher about your homework assignment

3. Have a conversation with a stranger if he/her talks to you first

4. Ask for instructions/clarification when you are confused about a task you must complete

5. Talk to a friend while waiting in line

6. Be an actor in a play

7. Describe the rules of your favorite game

8. Participate in a debate

9. Read part of an English novel

10. Read an English article in a paper

11. Read letters from a pen pal written in native English

12. Read personal letters or notes in which the writer has deliberately used simple words and constructions

13. Read an advertisement in the paper to find good merchandise, e.g. a book, you can buy

14. Read reviews in English for popular movies

15. Write an invitation to invite your schoolmates to a weekend party

16. Write down the instructions for your favorite hobby

17. Write a report on your favorite animal and its habits

18 . Write a story

19. Write a letter to a friend

20. Write a newspaper article

21. Write the answers to a "fun" quiz from a magazine

22. Write down a list of things you must do tomorrow

23. Listen to instructions in English and complete a task

24. Bake a cake if instructions were in English

25. Fill out an application form in English

26. Take directions from an English speaker

27. Understand an English movie 